\title{
An Overview of Saltpan Halophilic Bacterium
}

Manikandan $\mathbf{P}^{*}$ and Senthilkumar PK

Department of Microbiology, Faculty of Science, Annamalai University, Tamilnadu, India

*Corresponding author: Perumal Manikandan, Asst. Professor, Department of Microbiology, Annamalai, University, Annamalainagar, Tamilnadu, India, Tel: +04144-238248; E-mail: manimicroscien@gmail.com

Received date: August 18, 2017; Accepted date: October 17, 2017; Published date: October 18, 2017

Copyright: ( 2017 Manikandan P, et al. This is an open-access article distributed under the terms of the Creative Commons Attribution License, which permits unrestricted use, distribution, and reproduction in any medium, provided the original author and source are credited.

\begin{abstract}
Hypersaline environments provide an excellent medium for natural microbial communities which serve as a potential source of pharmaceutical substances. Salt is widely present in the earth. Almost $73 \%$ of earth was covered with marine water which contains $2.5 \%$ of common salt. Protease enzyme activity widespread in microorganisms, plant and animals. Proteolytic enzymes used in the industrial application and bioremediation process. In recent years' new mutant's microbe resistant to commonly used antibiotics. Protease inhibitors used as potential antibiotics for controlling microbial infections. A Hypersaline environment such as salt pans and salt lakes has high salt concentration and $\mathrm{pH}$. The saltpan provides a diversity of different environmental conditions of alkalinity, salinity, temperature, $\mathrm{pH}$ and nutrition. Halophilic organisms growing between 0.5 and $3.0 \mathrm{M}$ salt concentration. Extreme environments are the best source of bioactive compound producing halophiles microbes.
\end{abstract}

Keywords: Halophilic bacteria; Enzyme production; Biosurfactants; Bioremediation; Industrial uses

\section{Introduction}

Extreme halophiles are a group of microorganisms. They can able to grow in at various areas of high salt concentration. In the hypersaline environment, the salt concentration of the ocean is 3-5\% and the Dead Sea is $31.5 \%$. Halophiles were found in each domain of life primarily consist of archaea [1]. Extreme environments were characterized by extreme physicochemical conditions which make inhabitable for higher life forms [2]. Halophilic microorganisms used for enzyme production of valuable enzymes and bioactive compounds. Halophilic bacteria also produce secondary metabolites of extracellular polysaccharides such as proteins, enzymes, amylase, cellulases and amino acids etc $[3,4]$. Saltpans are large ponds filled with saltwater from the marine or another source. The salinity of the water gradually increases as water evaporates until it reaches saturation $\left(26 \%\right.$ at $\left.20^{\circ} \mathrm{C}\right)$. The salt then precipitates out and it's harvested. These hypersaline environments are commonly used in salt industries. These environments are favorable for halophiles which occurrence becomes visible due to the pigment production. Salt pan soil is characterized by saline soil, contains the high amount of soluble salts $\mathrm{Ca}^{2+}, \mathrm{Mg}^{2+}, \mathrm{K}^{+}$, and $\mathrm{Na}^{+}$. The dead sea contains many salts with different concentration $[5,6]$.

\section{Halophilic Bacteria}

Halophilic microorganisms are salt loving bacteria that inhabit in the hypersaline environments. These group is mainly prokaryotic and eukaryotic microorganisms. Normally halophiles living in the salt-rich environments that loss of water and die as a result of osmosis [7]. The halophilic and halotolerant bacterial media contain more than $5 \%$ salinity, some microorganisms are adapted different extreme environmental conditions of temperature like $\mathrm{pH}$, salinity, radiation and pressure [8,9]. The marine bacteria Bacillus pumilus and Halobacterium salinarum isolated from the soil sediment sample
[10,11]. The new halophilic genera, Halothermothrix, Halanaerobacter, Halocella, Acetohalobium and Orenia [12]. Solar saltpans are located originate all around the world and deliver ideal settings for halophilic and halotolerant bacteria [13]. Halophilic microbial yields are in tall demand in the pharmaceutical industry anywhere they have used an antidote to a variability of the plant, animal and human pathogens as well as the spare of some biochemical pesticides. The development of new molecular methods similar next generation sequencing has revolutionized our understanding of microbial ecology and detection of novel genes [14].

However, the intensive research focused the biotechnological applications of halophiles. Saline environments still offer a massive diversity of microbes with the potential to produce an array of natural products which can only be unlocked by concerted research efforts. Combination of culture and molecular approaches is employed to characterize halophilic bacteria from saltpan water samples and profile their potential biotechnological applications [15].

\section{Enzyme Production}

Halophilic bacteria produce various industrially important enzymes such as amylase and protease. These commercially important enzymes involved in the vital role of biotechnology [16]. Amylase enzyme is used in the pharmaceutical and treatment of digestive disorders [17]. This also used for various textile, detergent, food, paper and chemical industries. Protease enzyme used in medical, detergent and food processing industries. Amylases and proteases are also discovered from some microorganisms like bacteria, fungi and actinomyces but the genus Bacillus harvest has largest amylase activity. Isolation, identification and maintenance of these halophilic microbes are difficult; very few studies have been reported the applications [18]. However, only a minor fraction of the existing halophile diversity has been discovered, largely for enzyme production and other applications like the production of bioactive compounds and compatible solutes that are useful as stabilizers for bimolecular or stress protective agents [19]. The secondary metabolites of halophilic microbes contain a variety of bioactive compounds like lipopeptides, polypeptides, 
Page 2 of 5

polyketides, isocoumarins and macrolactins [20,21]. The significance of halophilic bacteria used in the salt making progression. This process accepted in the 1970s when it was realized that microorganisms play a role in responsible the quality and quantity of the salt harvested. The development of biological management performs for the operation of solar salterns [22]. Anaerobic microorganisms are interested in the extreme level environments because environmental parameters such as temperature and salinity regulate the rates of organic matter remineralization [23].

Extremozymes since halophilic archaea are not only extremely high salt tolerant nevertheless also thermal tolerant because the specific environment in which they living. They look to be the very good aspirant for industrial application, besides existence salt-loving, they may consume excellent activity, at high temperature, low water activity and high $\mathrm{pH}$. Present day, only a few reports have occurred on the characterization of halophilic archaea isolated from Algerian saline ecosystem that studies absorbed mainly on saline lakes [24-27].

\section{Biosurfactants}

Biosurfactants as a green over synthetic surfactant due to them lower toxicity to higher biodegradability and prodigious stability at altered physiochemical conditions [28]. The biosurfactants to reduce surface tension and form stable emulsions are a virtue for countless applications [29]. Besides, biosurfactants are to inhibit some pathogenic organisms. Numerous studies have optional, some powerful biosurfactants with broad spectrum activity contrary to anthropoid, plant and nourishment pathogens [30-32].

Halophiles may deliver organic compounds such as antimicrobials, enzymes, pigments, compatible solutes and lipids that are highly stable and active under extreme conditions and which strength have a biotechnological possible pharmaceutical, biosurfactants Laundry industry, food coloring [33,34].

\section{Enzymes}

The Cellulases enzymes that hydrolyze the cellulose molecule on the $\beta-1,4$ glycosidic bonds. Cellulases take an important share in the worldwide enzyme market owed to their various uses including cotton processing, paper recycling, detergent formulation, juice extraction, and animal feed additives for uses in agricultural biotechnology and production of transportation fuel (bioenergy) besides bio based products [35-37]. Amongst thermophilic bacteria, Bacillus species producing some extracellular polysaccharide-hydrolyzing enzymes, which consist of cellulose. Halophilic enzymes have salt enriched solvation ammos $[38,39]$. Proteomic analysis exposed that outer membrane proteins and periplasmic proteins of $N$. pentaromativorans are the major protein components of OMVNovo originated from the membrane-associated protein fraction. To the best of our knowledge, to first describe the OMV purified from halophilic marine bacteria [40].

The genus Bacillus is a substantial source of industrialized alkaline proteases and multiple Bacillus derived alkaline proteases take been purified and characterized [41]. Several Bacillus strains such as Bacillus caldoproteolyticus [42], Bacillus clausii [43], Bacillus subtilis [44], Bacillus karajensis [45], Bacillus sp haericus [46], Bacillus pseudofirmus [47], Bacillus tequilensis [48] and Haloalkaliphilic bacterium sp [49] Moderate halophile Halomonas heilongjiangensis [50]. Borderline extreme halophile Halosiccatus urmianus [51]. Extreme halophile Lentibacillus kimchi, [52]. Sporohalobacter salinus
[53]. Halo-tolerant Salinicoccus sediminis [54]. Halomonas hydrothermalis, Planococcus maritimus, Virgibacillus dokdonensis, Bacillus aquimaris [55].

\section{Bioremediation}

Bioremediation of voguish salty environment inexorably requires the application of halotolerant and halophilic microorganisms, which are able to grow under such harsh conditions. Externally added bacteria may contain some deleterious effects on the ecosystem, applying or activating the indigenous microflora is preferred if possible [56]. Halotolerant and halophilic bacteria are generally tolerating conspicuous amounts of toxic metals in their environment. Therefore, they were utilized in bioremediation of oil [17,57] Microbial degradation of azo dyes under anaerobic cultures often follows via an enzymatic reaction. This is outstanding to the strong electron withdrawing propensity of the azo groups associated with oxygen commencing the reduced electron carrier [58-61]. Many microorganisms are capable of decolorizing the azo dyes, including Gram-positive, Gram-negative bacteria [62-64] and some fungi $[65,66]$. This review highlights the various strategies adopted by the halophiles to compensate for their saline surroundings and includes descriptions of recent studies used these kind microorganisms for bioremediation of petroleum hydrocarbon polluted environments [67].

\section{Pharmaceutical Uses}

Consumption of Sea bio metabolites gained incredible importance in past few years because due to their potential values. Through the accumulative problem of drug resistance, there is a dire need to separate, identify and utilize newer molecules of biomedical prominence. Saltpans are stayed an extreme environment, which resides organisms that survive in high salinities, high temperatures withstand severe solar radiation. In future, these organisms could give an excellent support to sources of novel secondary metabolites. Several halophilic and halotolerant microbes inhabiting in the saltpans are yet to be fully explored as potential producers of pharmaceutically important molecules. Scarce reports are accessible on their antimicrobial potential in India [68-71]. They revised some of the topical new bioactive compounds from marine bacteria and fungi. Bacteria from Weihai solar saltern, China have been screened, applied usage of antimicrobial and cytotoxic activity of halophiles [72]. Extreme environments containing alkalophilic, oligotrophic, piezophilic, xerophilic and halophilic have willpower be the greatest source for bioactive compound producing microbes. The halophiles can be lightly classified as faintly, moderately or extremely halophilic be contingent on their necessity for $\mathrm{NaCl}$ [73].

\section{Industrial Uses}

Biopolymers are polymers, generated from renewable natural sources, are often biodegradable and not cause toxic to environments. They can be produced by microorganisms, plants and animals. Halophiles are organisms that prefer to live in habitats like saline and hypersaline environments with sodium chloride concentrations up to saturation [74].

Halophilic bacteria have the capability to produce compatible solutes which are beneficial for the biotechnological production of the osmoles. The solutes particularly glycine, betaines, and ectoines can be used as a stress protectant against high salinity, thermal denaturation, desiccation and freezing as well as stabilizers of enzymes, nucleic acids, 
membranes and entire cells. The industrial important applications of these compounds in enzyme technology are most encouraged. The other compatible solutes such as trehalose, glycerol, proline, ectoines, sugars, and hydroxyectoine. The halophilic bacteria have the highest efficiency of protection of lactate dehydrogenase against freeze-thaw treatment and heat stress. Moreover, halophilic bacteria produce a number of extra and intracellular enzymes and antimicrobial compounds that are commercial interest on the proteolytic enzyme from a reasonable halophile, Bacillus [75]. Halolamina salifodinae and Halolamina salina were isolated from a salt mine [76].

The role of halophilic bacteria in environmental biotechnology is promising for (1) recovery of saline soil (2), alkaline industrial wastewater (3) and degradation of toxic compounds. Halophilic microbes serve as a biotechnological potential source of compatible solutes, enzymes and additional compounds of industrial interest.

Halophilic microorganism produces a large variety of stable and exclusive biopolymers which have differentiated biological activities and hence are emerging with better and novel industrial and therapeutic applications. Their novel characteristics and capacity for largescale culturing make halophiles are potentially valuable for biotechnology important [77]. Halophiles are widely used in numerous common fermentation processes [78].

\section{Conclusion}

This review was clearly focused on Halophilic microorganisms consume initiate relatively few commercially feasible applications. Halophiles are produced a large variability of stable and unique biopolymers which have varied biological activities and hence are developing with greater novel industrial, therapeutic applications, treatment of saline or hypersaline wastewaters, the production of exopolysaccharides, bioplastics, biodegradation and biofuels. Biopolymers are got from halophiles. These are gaining tremendous importance because of their high stability in extreme salt conditions, with wide industrial and pharmacological applications.

\section{References}

1. Oren A (2002) Molecular ecology of extremely halophilic archaea and bacteria. FEMS Microbiol Ecol 39: 1-7.

2. Ramganesh S, Maredza A, Tekere M (2014) Microbial exploration in extreme conditions: Metagenomic analysis and future perspectives. In Metagenomics Methods, Applications and Perspectives, Nova Science Publishers 8: 157-181.

3. Dennis PP, Shimmin LC (1997) Evolutionary divergence and salinity mediated selection in halophilic archae. Microbiol Mol Biol Rev 61: 90-104.

4. Enache M, Kamekura M (2010) Hydrolytic enzymes of halophilic microorganisms and their economic values. Romanian J Biochem 47: 47-59.

5. Oren A (2002) Diversity of halophilic microorganisms: Environments, phylogeny, physiology and applications. J Ind Microbiol Biotechnol 28: 56-63.

6. Yaacov KB (1961) Some geochemical aspects of the dead sea and the question of its age. Geochemica Et Cosmochimica 25: 239-260.

7. Oren A (2001) The bioenergetic basis for the metabolic diversity at increasing salt concentrations: Implications for the functioning of Salt Lake ecosystem. Hydrobiologia 466: 61-72.

8. Rothschild LJ, Mancinelli RL (2001) Life in extreme environments. Nature 409: 1092-1101.

9. Rampelotto PH (2013) Extremophiles and extreme environments. Life 3: 482-485.
10. McLachlan J (1960) The culture of Dunaliella tertiolecta Butcher aeuryhaline organism. Can J Microbiol 6: 367-379.

11. Stolp Heinz (1998) Microbial ecology: Organisms, habitats, activities. Cambridge University Press Pp. 5-12.

12. Oren A (2004) Diversity of halophilic microorganisms: Environments, phylogeny, physiology, and applications. J Microbiol \& Biotechno 22: 60-63.

13. Cayol JL, Ollivier B, Patel BKC, Prensier G, Guezennec J, et al. (1994) Isolation and characterization of Halothermothrix orenii gen. nov., sp.nov., a halophilic, thermophilic, fermentative, strictly aerobic bacterium. Int J Syst Microbiol 44: 534-540.

14. Gupta S, Sharma P, Dev K, Srivastava M, Sourirajan AA (2015) A diverse group of halophilic bacteria exist in Lunsu, a natural salt water body of Himachal Pradesh, India. Springerplus 4: 274.

15. Selvarajan R, Sibanda T, Tekere M, Nyoni H, Meddows-Taylor S (2017) Diversity analysis and bioresource characterization of halophilic bacteria isolated from a South African Saltpan. Molecules 22: E657.

16. Temperton B, Giovannoni SJ (2012) Metagenomics Microbial diversity through a scratched lens. Curr Opin Microbiol 15: 605-612.

17. Margesin R, Schinner F (2001) Potential of halotolerant and halophilic microorganisms for biotechnology. Extremophiles 5: 73-83.

18. Moreno ML, Perez D, García MT, Mellado E (2013) Halophilic bacteria as a source of novel hydrolytic enzymes. Life 3: 38-51.

19. Waditee-Sirisattha R, Kageyama H, Takabe T (2016) Halophilic microorganism resources and their applications in industrial and environmental biotechnology. AIMS Microbiol 2: 42-54.

20. Hamdache A, Lamarti A, Aleu J, Collado IG (2011) Non-peptide metabolites from the genus bacillus. J Nat Prod 74: 893-899.

21. Bose U, Hewavitharana AK, Ng YK, Shaw PN, Fuerst JA, et al. (2015) LCMS-Based metabolomics study of marine bacterial secondary metabolite and antibiotic production in salinispora arenicola. Mar Drugs 13: 249-266.

22. DasSarma S, Arora P (1997) Genetic analysis of the gas vesicle gene cluster in haloarchaea. FEMS Microbio Letters 153: 1-10.

23. Davis JS (1974) Importance of microorganisms in solar salt production in: Proceedings of the 4th Symposium on Salt. 1: 369-372.

24. Tabuchi K, Kojima H, Fukui M (2010) Seasonal changes in organic matter mineralization in a sub littoral sediment and temperature-driven decoupling of key processes, Microbial Ecology 6: 551-560.

25. Kakhki AM, Amoozegar MA, Khaledi EM (2011) Diversity of hydrolytic enzymes in haloarchaeal strains isolated from Salt Lake. Int J Environ Sci Technol 8: 705-710.

26. Hacene H, Kebir K, Othmane DS, Lefebvre G (1994) HM17, a new polyene antifungal antibiotic produced by a new strain of Spirillospora. J Appl Bacteriol 77: 484-489.

27. Boutaiba S, Bhatnagar T, Hacene H, Mitchell DA, Baratti JC (2006) Preliminary characterisation of lipolytique activity from an extremely halophilic archaeon, Natronococcus sp. J Mol Catal 41:21-26.

28. ImadalouIdres N, Mlouka AC, Vandervennet M, Yahiaoui H, Peduzzi J, et al. (2013) Diversity and antimicrobial activity of cultivable halophilic Archaea from three Algerian sites. J Life Sci 7: 1057-1069.

29. Ebrahimipour G, Gilavand F, Karkhane M, Kavyanifard A, Teymouri M, et al. (2014) Bioemulsification activity assessment of an indigenous strain of halotolerant Planococcus and partial characterization of produced biosurfactants. Int J Environ Sci Technol 11: 1379-1386.

30. Kaya K, Morrison LF, Codd GA, Metcalf JS, Sano T, et al. (2006) A novel biosurfactant, 2-acyloxyethylphosphonate, isolated from waterblooms of Aphanizomenon flos-aquae. Molecules 11: 539-548.

31. Kim K, Yoo D, Kim Y, Lee B, Shin D, et al. (2002) Characteristics of sophorolipid as an antimicrobial agent. J Microbiol Biotechnol 12: 235-241.

32. AlitSusanta WGN, Takikawa Y (2006) Phenotypic characterization of Pseudomonas fluorescens PfG32R and its spontaneous gacS mutants and biocontrol activity against bacterial wilt disease of tomato. J Gen Plant Pathol 72: 168-175. 
33. Sinanoglou VJ, Zoumpoulakis P, Heropoulos G, Proestos C, Ciri CA, et al. (2014) Lipid and fatty acid profile of the edible fungus Laetiporus sulphurous. Antifungal and antibacterial properties. J Food Sci Technol 52: 3264-3272.

34. Tango MSA, Islam MR (2002) Potential of extremophiles for biotechnological and petroleum applications. Energy Sources 24: 543-559.

35. Litchfield CD (2011) Potential for industrial products from the halophilic Archaea. Ind Microbiol Biotechnol 38: 1635-1647.

36. Acharya S, Chaudhary A (2012) Bioprospecting thermophiles for cellulase production: A review. Braz J Microbiol 43: 844-856.

37. Phitsuwan P, Laohakunjit N, Kerdchoechuen O, Kyu KL, Ratanakhanokchai K (2012) Present and potential applications of cellulases in agriculture, biotechnology and bioenergy. Folia Microbiol 58: 163-176.

38. Venkatachalam S, Sivaprakash M, Gowdaman V, Prabagaran SR (2014) Bioprospecting of cellulase producing extremophilic bacterial isolates from India. British Microbiol Research J 4: 142-154.

39. Ladeira A, Cruz E, Delatorre B, Barbosa B, Martins (2015) Cellulase production by thermophilic Bacillus sp. SMIA-2 and its detergent compatibility. Electro J biotechnol 18: 110-115.

40. Yun SH, Lee SY, Choi CW, Lee H, Ro HJ, et al. (2017) Proteomic characterization of the outer membrane vesicle of the halophilic marine bacterium Novosphingobium pentaromativorans US6-1. J Microbiology 55: 56-62.

41. Madern D, Ebel C, Zaccai G (2000) Halophilic adaptation of enzymes. Extremophiles 4: 91-98.

42. Gupta R, Beg Q, Lorenz P (2002) Bacterial alkaline proteases: Molecular approaches and industrial applications. Appl Microbiol Biotechnol 59: 15-32.

43. Chen XG, Stabnikova O, Tay JH, Wang JY, Tay STL (2004) Thermoactive extracellular proteases of GeoBacillus caldoproteolyticus, sp. nov., from sewage sludge. Extremophiles 8: 489-498.

44. Oskouie SFG, Tabandeh F, Yakhchali B, Eftekhar F (2008) Response surface optimization of medium composition for alkaline protease production by Bacillus clausii. Biochem Eng J 39: 37-42.

45. Ghafoor A, Hasnain S (2009) Purification and characterization of an extracellular protease from Bacillus subtilis EAG-2 strain isolated from ornamental plant nursery. Pol J Microbiol 59: 107-112.

46. Heidari HRK, Ziaee AA, Schaller J, Amoozegar MA (2007) Purification and characterization of an extracellular haloalkaline protease produced by the moderately halophilic bacterium, Salinivibrio sp. strain AF-2004. Enzyme Microb Technol 40: 266-272.

47. Abd E, Moneim MR, Afify A, Aboul-Soud M, Foda M, et al. (2009) Production of alkaline protease and larvicidal biopesticides by an Egyptian Bacillus sphaericus isolate. Afr J Biotechnol 8: 3864-3873.

48. Sen S, Veeranki VD, Mandal B (2009) Effect of physical parameters, carbon and nitrogen sources on the production of alkaline protease from a newly isolated Bacillus pseudofirmus SVB1. Ann Microbiol 59: 531-538.

49. Bose A, Chawdhary V, Keharia H, Subramanian RB (2014) Production and characterization of a solvent tolerant protease from a novel marine isolate Bacillus tequilensis P15. Ann Microbiol 64: 343-354.

50. Dou G, He W, Liu H, Ma Y (2015) Halomonas heilongjiangensis sp. nov., a novel moderately halophilic bacterium isolated from saline and alkaline soil. Antonie Van Leeuwenhoek 108: 403-413.

51. Mehrshad M, Amoozegar MA, Makhdoumi A, Fazeli SAS, Farahani H, et al. (2016) Halosiccatus urmianus gen. nov., sp. nov., a haloarchaeon from a Salt Lake. Int J Syst Evol Microbiol 66: 725-730.

52. Oh YJ, Lee HW, Lim SK, Kwon M-S, Lee J, et al. (2016) Lentibacil- lus kimchii sp. nov., an extremely halophilic bacterium isolated from kimchi, a Korean fermented vegetable. Antonie Van Leeuwenhoek 109: 869-876.

53. Abdallah MB, Karray F, Mhiri N, Cayol JL, Tholozan JL, et al. (2015) Characterization of Sporohalobacter salinus sp. nov., an anaerobic, halophilic, fermentative bacterium isolated from a hypersaline lake. Int J Syst Evol Microbiol 65: 543-548.
54. Kumar RM, Kaur G, Kumar N, Kumar A, Singh NK, et al. (2015) Taxonomic description and genome sequence of Salinicoccus sediminis sp. nov., a halotolerant bacterium isolated from marine sediment. Int J Syst Evol Microbiol 65: 3794-3799.

55. Joghee NN, Jayaraman G (2016) Biochemical changes induced by salt stress in halotolerant bacterial isolates are media dependent as well as species specific. Prep Biochem Biotechnol 46: 8-14.

56. Dodia MS, Rawal CM, Bhimani HG, Joshi RH, Khare SK, et al. (2008) Purification and stability characteristics of an alkaline serine protease from a newly isolated Haloalkaliphilic bacterium sp. AH-6. J Ind Microbiol Biotechnol 35: 121-131.

57. Delille D, Basseres A, Dessomemes AA (1998) Effectiveness of bioremediation for oil polluted Antarctic seawater. Polar Biol 19: 237-241.

58. Margesin R, Schinner F (1999) Biological decontamination of oil spills in cold environments. J Chem Technol Biotechnol 74: 381-389.

59. Wuhrmann K, Mechsner K, Kappeler T (1980) Investigation on rate determining factors in the microbial reduction of azo dyes. Appl Microbiol Biotechnol 9: 325-338.

60. Zimmermann T, Kulla HG, Leisinger T (1982) Properties of purified orange II azo reductase, the enzyme initiating azo dye degradation by Pseudomonas KF46. J Biochem 129: 197-203.

61. Banat IM, Nigam P, Singh D, Merchant R (1996) Microbial decolorization of textile dye containing effluents: A review. Bioresour. Technol 58: 217-227.

62. Chen KC, WU JY, Liou DJ, Hwang SC (2003) Decolorization of the textile azo dyes by newly isolated bacterial strains. J Biotechnol 101: 57-68.

63. Sani RK, Banerjee UC (1999) Decolorization of triphenylmethane dyes and textile and dyestuff effluent by Kurthia sp. Enzyme Microb Technol 24: 433-437.

64. Kodam KM, Soojhawon I, Lohande PD, Gawai KR (2005) Microbial decolorization of reactive azo dyes under aerobic conditions. Word J Microbiol Biotechnol 21: 367-370.

65. Moosvi S, Kehaira H, Madamwar D (2005) Decolorization of textile dye Reactive Violet 5 by a newly isolated bacterial consortium RVM 11.1. World J Microbiol Biotechnol 21: 667-672.

66. Balan DSL, Monteneiro RTR (2009) Decolorization of textile indigo dye by ligninolytic fungi. J Biotechnol 89: 141-145.

67. Edbeib MF, Wahab RA, Huyop F (2016) Halophiles: Biology, adaptation, and their role in decontamination of hypersaline environments. World J Microbiol Biotechnol 32: 135.

68. Verma P, Madamwar D (2005) Decolorization of Azo dyes using Basidiomycete strain PV 002. World J Microbiol Biotechnol 21: 481-485.

69. Dhanasekaran D, Rajakumar G, Sivamani P, Selvamani S, Panneerselvam A, et al. (2004) Screening of salt pans actinomycetes for antibacterial agents. The Internet J Microbiol 1: 1-4.

70. Kamat T, Kerkar S (2004) Studies on a bioactive compound produced by a halotolerant saltpan isolate. Conf on Microbiol of Tropical Seas (COMITS) 10: 13-15.

71. Kamat T, Kerkar S (2007) Profiling the bioactive potential of an Acinetobacter sp. from Ribandar saltern in Goa. Natl Sem on New Trends in Biotechnol 11-12.

72. Vidyasagar M, Prakash S, Jayalakshmi SK, Sreeramulu K (2007) Optimization of culture conditions for the production of halothermophilic protease from halophilic bacterium Chromohalobacter sp. TVSP101. World J Microbiol Biotechnol 23: 655- 662.

73. Ghosh R, Chattopadhyay PK, Chattopadhyay B, Pal D (2010) Antibiotic resistance profile of halophilic microorganisms isolated from tannery effluent. Indian J Biotechnology 9: 80-86.

74. Shifa AG, Zeba ASZ, Vinod PS, Sulochana MB (2016) Molecular characterizations and screening of halophiles for the production of biopolymers. European J Biotechnol Biosci 4: 32-36.

75. Kamekura M, and Onishi H (1974) Protease formation by a moderately halophilic Bacillus strain. Appl. Microbiol 27: 809-810.

76. Zhang WY, Huo YY, Zhang XQ, Zhu XF, Wu M (2013) Halolamina salifodinae sp. nov. and Halolamina salina sp. nov., two extremely 
Citation: Manikandan P, Senthilkumar PK (2017) An Overview of Saltpan Halophilic Bacterium. J Antimicrob Agents 3: 151. doi: 10.4172/2472-1212.1000151

Page 5 of 5

halophilic archaea isolated from a salt mine. Int J Syst Evol Microbial 63: 4380-4385.

77. DasSarma S, Arora P (2017) Halophiles. Encyclopedia of Life Sciences.
78. Gostincar C, Lenassi M, Cimerman NG, Plemenitas A (2011) Fungal adaptation to extremely high salt concentrations. Adv Appl Microbiol 77: 71-96. 